http://dx.doi.org/10.1590/1678-4162-8685

Arq. Bras. Med. Vet. Zootec., v.69, n.1, p.10-14, 2017

\title{
Congenital multiple arthrogryposis in bovine
}

[Artrogripose congênita múltipla em bovino]

\author{
D.P. Vrisman ${ }^{1}$, D.V. Bonato ${ }^{2}$, A.R. Taira ${ }^{3}$, E.R. Thomaz ${ }^{3}$, J.A. Peres ${ }^{3}$, C.A.S. Malta ${ }^{2}$, C.A. Cintra ${ }^{2}$, \\ M.S. Cunha ${ }^{2}$, L.N. Coutinho ${ }^{4}$, L.Z. Crivellenti' ${ }^{2}$, G.M. Magalhães ${ }^{2}$, P.P.M. Teixiera ${ }^{2 *}$ \\ ${ }^{1}$ Universidade Estadual Paulista Júlio de Mesquita Filho - Jaboticabal, SP \\ ${ }^{2}$ Universidade de Franca - Franca, SP \\ ${ }^{3}$ Universidade Estadual do Centro-Oeste - Guarapuava, PR \\ ${ }^{4}$ Universidade Federal Rural da Amazônia - Belém, PA
}

\begin{abstract}
This report describes an anal atresia, anatomical urethra alteration (slightly caudal to the udder), thickened joints, and changes in the pelvis in a newborn Holstein cow. Visualization of the final portion of the rectum was not possible by perineal access and laparotomy through the right flank was performed in order for abdominal exploration and colostomy attempt. During the surgical procedure visceral rupture and malformations incompatible with life were observed, so surgeons opted for euthanasia and necropsy. Alterations were confirmed in the genitourinary and gastrointestinal tract. The non-formation of the anus caused dilation of the distal portion of the rectum with fecal content retention, which was drained to the body of the uterus, with the presence of meconium. This amount of anatomical and clinical changes were diagnosed as congenital multiple arthrogryposis.
\end{abstract}

Keywords: anal atresia, environmental contaminants, genitourinary malformations, fetal monstrosity

\section{RESUMO}

Este relato de caso descreve atresia anal, alteração anatômica da uretra (inserida caudalmente ao úbere), articulações espessadas e alterações na pelve em um neonato bovino da raça Holandesa. A visualização da porção final do reto não foi possível pelo acesso perineal, e laparotomia através do flanco direito foi feita para exploração abdominal e realização da colostomia. Durante o procedimento cirúrgico, foram observadas ruptura visceral e malformações incompatíveis com a vida, então os cirurgiões optaram pela eutanásia e necropsia. Alterações foram confirmadas nos tratos geniturinário e gastrointestinal. A não formação do ânus causou dilatação da porção distal do reto com retenção fecal, desviando ao corpo do útero, o qual possibilitou a entrada de mecônio nesse compartimento, além de outras alterações devido à ingestão e alteração no trânsito gastrointestinal. Essa quantidade de alterações anatômicas e clínicas foi diagnosticada como artrogripose congênita múltipla.

Palavras-chave: atresia anal, contaminantes ambientais, malformações geniturinárias, monstruosidades fetais

\section{INTRODUCTION}

The congenital defects, such as structural and functional abnormalities of tissues, organs, and systems occur in embryonic or fetal development stages in most animal species. Hereditary causes, external factors such as toxic plants or chemicals, and some cases due to idiopathic causes are the

Recebido em 18 de agosto de 2015

Aceito em 7 de julho de 2016

*Autor para correspondência (corresponding author)

E-mail: p_paulomt@yahoo.com.br most ordinary etiology (Marcolongo-Pereira et al., 2010). Congenital defects are anomalous changes, present at birth, as consequence of failure of one or more constituents of the body (Cristo et al., 2012; Voitena et al., 2012). Structure or function of the body's systems ranging from small deviations, to moderate or serious defects and monstrosity. They generally do not have defined causes, related to 
environmental and genetic factors, or even the interaction of these. Due to the rarity of these anomalies, their cause is difficult to determine (Bertoli et al., 2014).

Arthrogryposis can often occur in newborn bovine with enlargement and rigidity of joints. The rigidity is a primary muscle injury, dysplasia/amyoplasia or neurogenic atrophy resulting from the absence of motor neurons in the spinal cord or demyelination of motor nerves. This change may occur due to involvement of recessive hereditary characteristics, viral infections, or poisonous plant ingestion (Silva et al., 2005; Marcolongo-Pereira et al., 2010). However, the congenital multiplex form as described in humans, has not be described in ruminants to date. Congenital multiple arthrogryposis is reported in children, characterized by a heterogeneous group of congenital disorders of unknown etiology, probably multiple, characterized by extreme stiffness and contracture of joints (usually flexion), associated with hypoplasia or absence of muscle and soft tissue development (Schmidt and Oliveira, 2014), especially in gastrointestinal and genitourinary tract. Moreover, multisystem abnormalities complex with musculoskeletal, cardiovascular, ophthalmic otorhinolaryngological can also be present (Moreira et al., 2001).

Thus, the aim of this study is to report a case of a bovine with multiple congenital defects, especially in the digestive and genitourinary tract similar to the reported in humans with congenital multiple arthrogryposis.

\section{CASE REPORT}

The case involves a Holstein breed cow, at one day of life, with malformation in the digestive tract (DT) and genitourinary tract (GUT) history. The owner reported to having provided 2 liters of colostrum to the patient before presenting the animal to the Veterinary Hospital. During clinical evaluation, colic attacks and some anatomical defects were observed, as anal sphincter agenesis, coccygeal vertebrae agenesis, sacral vertebrae defects as well as changes in the external genitalia and deviation of external urethral orifice in the ventral region of perineum, close to the insertion of the udder (vulva was not identified in the perineal region) (Fig. 1A and B). A thickening in femorotibiopatelar and radiometacarpal joints was also noticed, however the patient apparently did not exhibited any lameness or limited mobility. Complete blood count $(\mathrm{CBC})$ and biochemical parameters were within their respective reference intervals. Abdominal sonographic evaluation showed abdominal fluid and suggested alterations on DT and GUT.

The first procedure was done to assess the final portion of the rectum to create a rectal neoesfincter. Unfortunately, due to rectum localization and pelvic deformity, a second access on the right flank was necessary, also as exploratory purpose and colostomy in order to maintain gastrointestinal transit.

During the exploratory laparotomy, there were many congenital changes of DT, such as anatomical changes of the colon, feces in the cavity and the uterus communication with intestine (Fig. 1C). Thus, due to the large number of defects and the peritonitis, we opted for euthanasia and necropsy.

On necropsy we observed stiffness and swelling of femurotibial joints. In the thoracic cavity, diffuse pulmonary edema, resulting from pneumonia by aspiration. In the abdominal cavity, there was moderate accumulation of greenish yellow liquid without characteristic odor. Irregular development of the uterine horns with cyst formation in the serosa surface (Fig. 1D). Ovaries were absent, and in the region there was only a fibrous capsule, containing odorless citrine liquid inside. 


\section{Vrisman et al.}

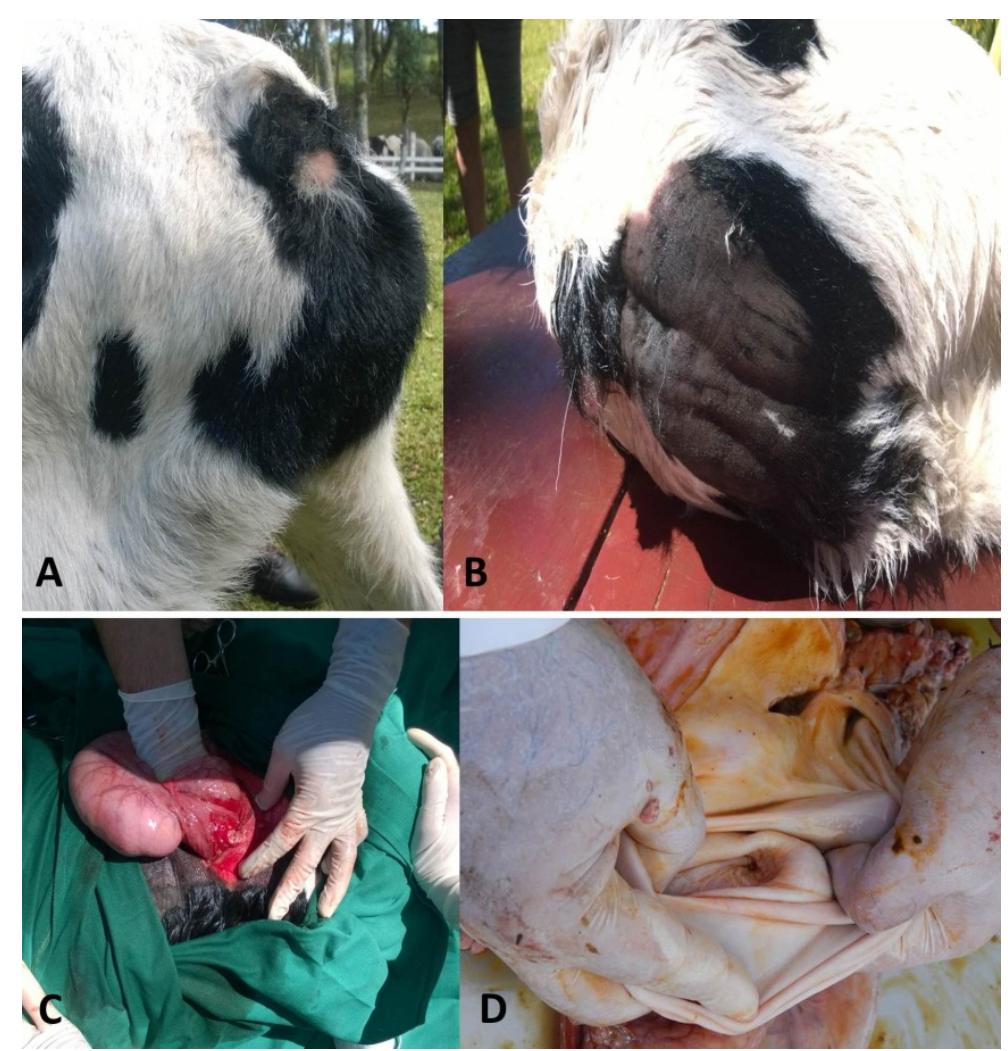

Figure 1. Bovine with congenital multiple arthrogryposis. A and B: Perineal region with anal atresia, pelvis malformation and agenesis of the coccygeal vertebrae. C: Macroscopic image of part of the uterine horn during the surgery. D: uterine cervix found on necropsy.

Inside the uterine horns there was a yellow-green liquid content, moderately viscous, odorless, and associated with the presence of nodular pasty formations characterized as meconium. The large intestine and rectum had a marked expansion in the distal segment, and communicated with the uterus at the uterine horn bifurcation (Fig. 2A, B and $\mathrm{C}$ ); mucosa was thickened and had a firm consistency. We also observed the presence of diverticulitis on the entire length of both uterine horns.

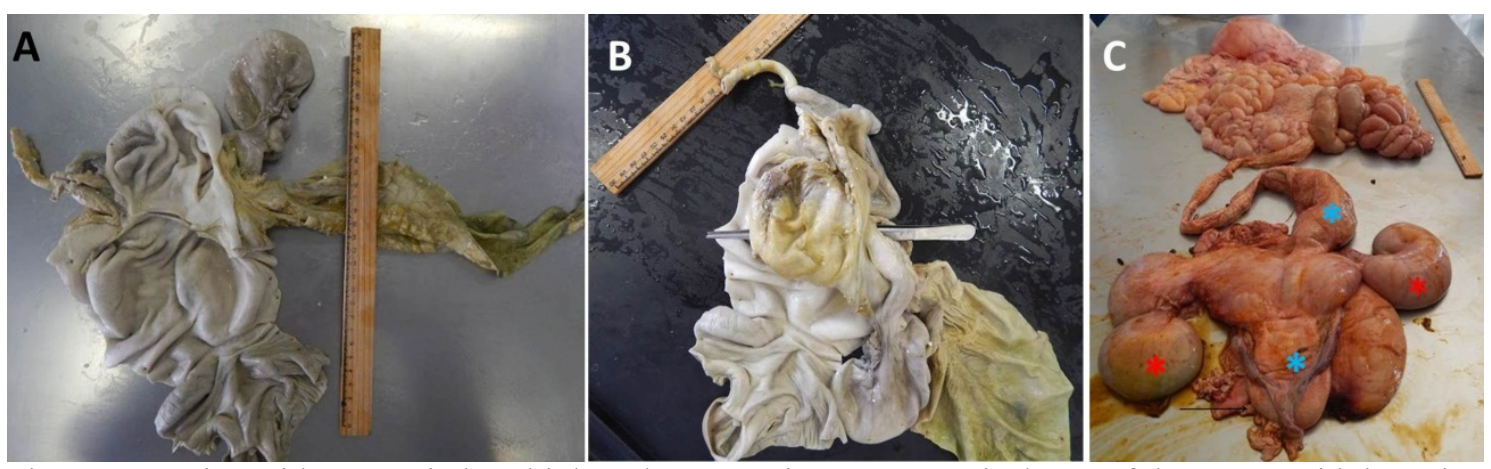

Figure 2. Bovine with congenital multiple arthrogryposis. A: Anatomical part of the uterus with insertion of the colon. B: Colon insertion area in the uterus (anatomical forceps). C: Uterus (* red), intestine (* blue), and male reproductive tract part (arrow). 
Two tubular structures of firm consistency, thickened, that in the cut showed the presence of urine content, lead to an exit hole along the perineal region. This segment protruded toward the subcutaneous tissue, following what would be the formation of a penile urethra, and male sex glands, underdeveloped (Fig. 2C).

Histologically, in the large intestine we observed segments with no secretory glands, irregular distribution of smooth muscle fibers, intense hyperplasia in the mucosa, myocyte hypertrophy associated with diffuse neovascularization, hyperemia and intravascular inflammatory mononuclear cells. The middle muscle smooth layer forms myocyte conglomerates, associated with diffuse proliferation of connective tissue (fibroblasts in nodules shape). Atrophy and irregular hypertrophic epithelial cell distribution in the mucosa.

In the ureter we observed the transitional epithelium composed of hypotrophic epithelial cells with intense keratinization, gathering toward the middle layer (longitudinal layer), irregularly infiltrating among rare muscle fibers with hypoplastic and hypotrophic myocytes with moderate vascularization.

We found a shapeless endometrium epithelium, predominantly hypertrophic epithelial stem cells with fibroblast irregular infiltration favoring intense collagenous degeneration and neovascularization. Infiltrating fibroblast projects irregularly to medium layer in the longitudinal portion lying with the same cells arranged in the joint portion (bowel transition) and changed uterus by severe necrosis and diffuse collagenous degeneration coming to glandular secretory epithelium associated with fibroblasts (connective tissue) in the lamina propria, where we observed degenerated neutrophils. Epithelial syncytial cells characterize uterine structure differing from the bowel.

Given the joint changes, concurrent with systemic multiple changes, with greater emphasis on the genitourinary and gastrointestinal tracts similar those found in humans, we suggest this case is the first case of congenital multiplex arthrogryposis.

\section{DISCUSSION}

The most similar, to the present case, was the report of anal atresia, congenital urethrorectal fistula, accessory scrotum, and pseudohermaphroditism in a calf including some abnormalities in genitourinary and gastrointestinal tracts (Rocha et al., 2010). Although arthrogryposis with these abnormalities have not be described in cow before, due to the similarity we may conclude that this abnormality could be demonstrated in different degrees or maybe joints were not assessed in that case.

The occurrence of congenital malformations in cattle is sporadic, in this animal, we found joint changes, the capsule was thick and showed intense dislocation and did not allow the free movement of the member, as described in arthrogryposis cases (Silva et al., 2005). Due to the difficulty in assessing locomotion in newborn cow, we cannot mention that there was any musculoskeletal loss.

Surgical intervention by exploratory laparotomy was not the first choice because anal atresia is the most common malformation of the hindgut. During necropsy we observed that the nonformation of the anal orifice promoted the intense expansion of the distal portion of the rectum with fecal content retention. This content was shifted by a fibrous hole on the body of the uterus, which enabled the meconium entry into the uterine horns. Irregular mucosal projections, forming diverticulitis, favored the diffuse fibrosis of the mucosa with cystic formation in ovaries and external uterine and digestive structures during the microscopic examination of the intestinal mucosa, we could observe the incomplete formation of it structures, with only serous formation (Vianna and Tobias, 2005; Voitena et al., 2012; Rocha et al., 2010).

Although no laboratory abnormality was seen, we suppose due to short period of life, it was not possible to show post-renal azotemia from obstruction or alteration in CBC.

Even if the anal atresia had been corrected due to malformation of the large intestine, the segment would not have peristalsis to eliminate fecal content; the ovariohysterectomy is not recommended because of the absence of hormones, disturbing the development of the 
animal; and joint defects would possibly limit its locomotion during development.

\section{REFERENCES}

BERTOLI, G.; MENDES, J.P.; FILADELPHO, A.L. et al. Dicefalia em bovino: relato de caso. Rev. Cient. Elet. Med. Vet., v.23, p.1-9, 2014.

CRISTO, A.B.; LEMKE, B.V.; PERINI, R. et al. Ciclocefalia em bovinos: relato de caso. Rev. Cient. Eletr. Med. Vet., v.19, p.1-19, 2012.

MARCOLONGO-PEREIRA, C.; SCHILD, A.L.; SOARES, M.P. et al. Defeitos congênitos diagnosticados em ruminantes na região sul do Rio Grande do Sul. Pesqui. Vet. Bras., v.30, p.816-826, 2010.

MOREIRA, A.T.R.; TEIXEIRA, S.; RUTHES, H.I. et al. Síndrome de Moebius associada a artrogripose: relato de caso e revisão da literatura. Arq. Bras. Oftalmol., v.64, p.576-579, 2001
ROCHA, T.G.; LASKOSKI, L.M.; LOPES, M.C.S. et al. Anal atresia, congenital urethrorectal fistula, accessory scrotum and pseudohermafroditism in a crossbred calf. Cienc. Rural., v.40, p.1231-1234, 2010.

SCHMIDT, V.; OLIVEIRA, R.T.D. Arthrogryposis in a goat: a case report. Arq. Bras. Med. Vet. Zootec., v.56, p.438-440, 2004.

SILVA, L.A.F.; FRANCO, L.G.; EURIDES, D. et al. Aspectos clínicos, ocorrência e tratamento de artrogripose cárpica congênita em bezerros em uma população de 27300 bovinos. Acta Sci. Vet., v.33, p.131-137, 2005.

VIANNA, M.L.; TOBIAS, K.M. Anal atresia in the dog: a retrospective study. J. Am. Anim. Hosp. Assoc., v.41, p.317-322, 2005.

VOITENA, J.N.; FILADELPHO, A.L.; BIRCK, A.L. et al. Anal atresia and tail agenesis in swine: case report. Rev. Cient. Eletr. Med. Vet., v.19, p.1-20, 2012. 